Mojca Ilc Klun

\title{
The Importance of Individual Memories of Slovenian Emigrants When Interpreting Slovenian Emigration Processes
}

Keywords: Slovenian emigration, diaspora, migration, biographical-narrative methodological approach, life stories, memories

DOI: $10.4312 /$ ars.13.1.174-190

\section{Introduction}

Because of its transit position, historical development, economic, political and social factors, the area of Slovenia has been constantly involved in migration processes, or, as Drnovšek says (1991), has been "a place of constant movement of people and mixing of civilizational and cultural influences" (Drnovšek, 1991, 14). In the context of migration processes, we can, during different periods, categorize Slovenia as:

- An emigration country: The largest emigration processes happened during the last decades before the First World War when one third of the population from Slovenia left the country (Drnovšek, 1999). The second largest happening after the Second World War.

- An immigration country: In the 1960s Slovenia experienced a kind of "migration revolution", when it had transformed from a country of emigration to the country of immigration (Malačič, 1991; Malačič, 2008). According to statistical data, we can also categorize Slovenia as an immigration country in the present (SURS, 2018).

- A transit migration country: Since the 1960s, Slovenia has also been a part of transit migration routes, in which people from mainly "ex-Yugoslavia" cross the country to enter other western, central, or northern European countries. But we must stress that those transit migration routes were limited to individuals or small groups. As part of a massive transit migration route, we can highlight the period between 2015-2016, when Slovenia was part of the so-called Western Balkan migration route. Over the course of five months (October 2016 - March 2016) more than 460,000 migrants crossed through Slovenia (Ilc Klun, 2017a). 
Considering the fact that Slovenia has always been involved in different migration processes, the question arises: "How well are migration-related topics included into the Slovenian educational system?” Through its educational system, each country provides an educational standard and educational topics for its citizens which are in accordance with the social needs, interests, and developmental tendencies of the nation. Studies from 2016-2017 (Ilc Klun, 2017) show that in the Slovenian educational system issues related to migration and the Slovenian diaspora are usually omitted from obligatory parts of the school curricula and textbooks, and are therefore not a part of primary and secondary school education. This leads to a situation where young people's knowledge and understanding of migration processes and the Slovenian diaspora are at a very low level (Ilc Klun, 2017). For example, a study from 2017 shows that among 1,103 primary and secondary school students, less than half (45.5\%) could define the term "emigrant", and less than a quarter $(24.8 \%)$ the term "economic migrant". More than $60 \%$ of them answered "I do not know" to various questions and claims about Slovenian emigration processes (Ilc Klun, 2017). We also must highlight that a study from 2016 shows that social media has a significant impact on student's opinions when talking about migration (Ilc Klun, 2017a). If we add to these results the following facts than we can conclude that migration related topics should be a part of each educational system, including Slovenia's:

- migration processes are nowadays one of the most evident demographic processes, which influence population dynamics(Salzmann et al., 2010);

- $\quad$ statistical projections show that in the future migration processes will be much more intense and numerous compared to those in the past ${ }^{1}$ (Kovač, 2003);

- $\quad$ in September 2015 the United Nations General Assembly in New York adopted the Agenda for Sustainable Development 2030, which also mentions migration as an important element for sustainable development. One of the objectives of the Agenda 2030 states that countries will ensure secure, legitimate, and responsible migration with well-planned and well-managed migration policies (Agenda 2030, 2015).

In our opinion, a person can better understand global migration issues when they understand their own nation's migration processes. For this reason we believe that Slovenia's education system should be required to include topics about the Slovenian diaspora as a part of the general curriculum.

A study from 2017 showed that students in primary and secondary schools are not particularly interested in migration related topics or the Slovenian diaspora

1 According to the United Nations there were 200 million international migrants in 2010 (Salzmann et al., 2010), 232 million in 2013 (International Migration Report, 2013), 244 million in 2015 (International Migration Report 2015, 2016) and 258 million in 2017 (Population Facts, 2017). 
(Ilc Klun, 2017). The majority of them stated that the way migration-related topics are taught in schools is not interesting, and they find both the teaching materials and methods uninteresting and outdated (Ilc Klun, 2017). This raises the challenge and need to create new teaching materials that would engage and motivate Slovenian students when it comes to learning about migration processes, while also helping them better understand the past and present emigration processes of Slovenians. Because of the strong emotional effects, we decided that the most appropriate teaching material would be a book containing real life stories of the Slovenian diaspora, including the memories and personal experiences of people who engaged in such journeys. Through the memories and life experiences of the Slovenian diaspora, students in Slovenia could better understand not just our (Slovenian) migration processes, but also be able to make comparisons between past and present Slovenian and global migration processes. They could also gain a better understanding that all immigrants, including Slovenian ones, face the same challenges when emigrating from their homeland or when immigrating to a new country. Real life stories (written or spoken online) are used in different educational systems around the world for teaching different topics, not just those related to migration (e.g. UNESCO stories). Teachers also use real life stories of migrants to explain emigration and immigration processes, push and pull factors, the processes of integration in new social environment, etc. Cameron (2012) states that "Story $\ldots$ is an expressive method and an effective tool, designed both to demonstrate affective and emergent geographies and to move audiences toward new realms of thought and practice" (Cameron, 2012, 575). Narrative learning is a relatively new concept in which the link between living and telling a story, and learning from it, has been established (Kragh Blume Dahl, 2015). The concept underlying how we learn through narratives (real life stories) has recently been theorized by different authors. Clark and Rossiter (2008) state that through real life stories readers learn about the experiences of the person who tells the story (Clark, Rossiter, 2008). They also state that meaning-making is a narrative process, through which the storyteller express their identity (Clark, Rossiter, 2008; Clark, 2010). We can also characterize narratives as stories about human lives that feature different social events and have personal meaning (Goodson, Gill, 2011).

\section{Methodological approaches}

The idea of creating new teaching material, a book of real life stories, was born during the scientific and research work undertaken in the period 2014-2017, when the results of different analyses (school curricula, textbooks) and studies among students showed the following: 
- topics related to migration and the Slovenian diaspora are in general excluded from obligatory parts of the Slovenian school curricula and textbooks;

- $\quad$ students in Slovenia are not interested in the Slovenian diaspora;

- students find that the presentation of Slovenian-emigration related topics is uninteresting;

- $\quad$ students are not motivated to learn or research topics about the Slovenian diaspora (Ilc Klun, 2017).

In the process of creating new teaching material, our goal was to show students that:

- topics related to the Slovenian diaspora can be interesting;

- $\quad$ knowledge of the Slovenian diaspora can help them to better understand concepts such as global migration processes, the causes of emigration and immigration, refugees, a multicultural society, adaptation to a new social environment, integration, migration policy, etc.;

- knowledge of Slovenian emigration can help bring clarity to certain periods of Slovenian history;

- Slovenians have also been involved in different global migration processes;

- members of the Slovenian diaspora, as immigrants in foreign countries, have faced similar challenges to immigrants in Slovenia or in other countries;

- when learning or researching about the Slovenian diaspora, we are not only dealing with the past emigration processes of Slovenians, but we can also monitor the recent and current migration trends of Slovenians;

- $\quad$ we can, when learning and researching about these topics, raise awareness with regard to a multicultural society and related issues.

To create the new teaching material we choose to collect real life stories of the Slovenian diaspora, because we believe that by presenting such topics through real life stories students can obtain a more detailed, in-depth, interesting, and personal overview of the topic.

For developing the real life stories we decided to use the biographical narrative methodological (BINM) approach, which is quite widespread and well developed in different areas of social studies (Wengraf, 2004; Meares, 2010; Roseneil, 2012), but is still rarely used in Slovenia. The BINM approach is a qualitative methodological approach and is one of the forms of unstructured in-depth interviews. It has evolved as an innovative method which has helped explain various social phenomena, including those related to migration. In the $18^{\text {th }}$ and $19^{\text {th }}$ centuries historians already used letters, diaries, personal testimonials, and photographs (so-called biographical materials) in order to explain important social events (Pajnik, Bajt, 2009). Later this methodological 
approach was applied to other sciences - sociology, psychology, and anthropology, and recently it has gained more popularity in both gender studies and those of migration processes.

We conducted research in the period 2015-2016. Using the BINM approach we gathered 56 unstructured in-depth interviews with people who claim themselves to be a part of Slovenian diaspora (either they emigrated from Slovenia or their parents or grandparents did). Due to the long distance between interviewee and questioner, all the interviews were conducted online with different mobile and online applications (Skype, Viber, Facebook, Messenger, etc). For each interviewee we created a special form where we collected their personal data and wrote their narrative, memories, expressed ideas, messages, and feelings. To begin the online interview we prepared starting questions to help build a more open relationship between the interviewee and questioner. After this we set up the main task of the interview - we invited the interviewee to share their own story with us in relation to migration processes from Slovenia. The story-telling was left completely to the interviewee, who built their life story based upon their individual memories. The interviewee told their life story as they wanted to, revealed the events they felt that were important, and explained what they wanted. In this phase of the methodological approach, the questioner was only an active listener, who wrote down what was reported along with questions that might have come up during the narration. When the interviewee has finished their story, the questioner then asked additional questions for clarity. In the last phase of the BINM approach, the questioner wrote a story based on the real life story of the interviewee, in order to use it for educational purposes.

The final result of our biographical narrative methodological approach is a book of 56 real life stories, where individual memories are shared. Through the individual memories of the interviewees, an image of the Slovenian diaspora can be built. We want to highlight that every interviewee had the right to tell their own life story using their own memories, which might differ from the memories of someone else. Every story was written using simple, understandable language, and only the names of the interviewees were changed in order to keep their identities private, while the rest of the information remained untouched. The final result of the BINM approach is a book called Stories - often told, but never written stories of people of Slovenian descent from USA, Canada, Australia and New Zealand, in which 56 people of Slovenian descent tell their stories. These can be used when teaching, learning or researching issues related to migration and/or Slovenian emigration. 


\section{Results and discussion}

In the following tables we present three real life stories which could help students to better understand migration-related topics, especially in relation to Slovenian emigration. Each story was told by a member of the Slovenian diaspora, based on their individual memories. In addition to each story, we discuss significant general migration-related facts, which are important for building knowledge about global and Slovenian, migration processes, and both in the past and present. These selected life stories are a good example of how students could learn about migration related topics through the individual memories of those who migrated themselves or whose ancestors did.

Table 1: The real life story of a person of Slovenian descent from the USA. (Ilc Klun, 2017b)

My roots originate from astounding Slovenia (Lory, USA)

"Both of my grandparents were Slovenian. They met during the Second World War when my grandfather, as a member of the anti-communist party "domobranci", was settled in Borovnica. When the war was finished, communists assumed power and began to kill members of "domobranci". This caused my grandparents to emigrate from Slovenia and flee to refugee camps in Austria and Germany. After a few years, one of my grandmother's aunts, who already lived in the USA, financially supported my grandparents, which helped them in their emigration to Chicago. There were also five children who emigrated with them at that time. All of the remaining family members of my grandmother stayed in Borovnica, and all of my grandfather's relatives stayed in Celje. The family has continued to uphold the values they brought with them from their homeland of Slovenia. These were: God, family, nation, and homeland. It was with these values that we, immigrant children
Analysing the facts of the story building up knowledge

Second World War: After the Second World War, a period of politically motivated emigration from Slovenia occurred. According to statistical data, around 18,000 Slovenians emigrated during the first few years after the war and later, as so-called chain-migrants, another 11,000 Slovenians left (Zupančič, 1998).

Refugee camps: Slovenians who did not agree with the political system during and after the Second World War first emigrated to refugee camps. After a few years of living in such camps, they mainly emigrated to Argentina, the USA, Canada and Australia (Ilc Klun, 2017).

Financial support: When leaving Slovenia, emigrants needed financial support in order to immigrate to the USA. If they did 
and grandchildren, were raised by. We were aware of our Slovenian roots, which originate from the astounding country of Slovenia, which we enjoy visiting, too. We also try to preserve Slovenian culture and tradition here in the US.

My grandma and her best friend, as well as the association Triglav, taught me about my Slovenian heritage and traditions, including Slovenian national costumes, the blessing of Easter food, the knowledge of Slovenian history and culture. With my grandmother and her best friend, who was also Slovenian, we baked "potica" for each holiday.

I do not think about moving to Slovenia, since I did not learn the Slovenian language. My mother, who was a child of immigrant parents, never taught me Slovenian, so I would have difficulty getting a job in Slovenia. I also have a very big family in the US - aunts, uncles, cousins. All my eight aunts and uncles speak Slovenian fluently. When the family immigrated to the USA, they did not speak any English at home, as they tried to preserve the Slovenian language." (Ilc Klun, 2017b) not have this from a relative or acquaintance, they were not able to go to the USA (Ilc Klun, 2017).

Slovenian roots: When immigrating to the US, Slovenian emigrants tried to preserve Slovenian culture in their families. They kept some Slovenian traditions, the most common being those related to baking and cooking (Ilc, 2006).

Triglav: Slovenian emigrants established Slovenian institutions in their new "homeland" (Ilc, 2006; Ilc Klun, 2017). They mostly named these institutions after significant Slovenian symbols, such as Triglav. Slovenian language: Many children of Slovenian emigrants did not speak any English until they entered primary school. In the beginning, their parents did not know much English, and therefore insisted on speaking Slovenian at home.

Table 2: The real life story of a person from Slovenia who immigrated to Canada.

I travelled to Canada as a young girl and as a woman I created a beautiful life there (Marjana, Canada)

"It was in 1970 when my husband and I made a decision to leave Slovenia and emigrate to Canada because of an unstable family situation. We received a green card and a guarantee letter by post and left as quickly as possible. Before the departure we had to pass many medical examinations and provide
Analysing facts of the story building up knowledge

Unstable family situation:

Despite the fact that economic and political reasons for emigration prevailed, in some cases we can find other reasons, such as those related to family situations, religion, the military, etc. 
all the necessary documentation that would allowed us to enter Canada. Doctors in

Zagreb and Belgrade examined us and issued us certificates that proved we did not have any infectious diseases that could potentially infect Canadians or passengers on the plane. When we collected all the necessary papers and airfare, we got on the road that led us through Germany and Montreal to Toronto. In Toronto my husband's brother met us. He sent us a guarantee letter, assuring that he would help us to find a job, support us financially, and rent us an apartment. Those things allowed us to immigrate to Canada. He was also the one who had suggested that we immigrate to Canada, because he had been living there for five years and he had already obtained Canadian citizenship. At first, we intended to stay in Canada for only five years, earn some money, and return to Slovenia. But the plans changed. In the meantime, we bought the house, we had children, and after five years, we became Canadian citizens. Suddenly, we no longer felt the need to return home to Slovenia. We created our little home under the Canadian sun. In the autumn of 1970, my husband and I enrolled for a two-year English course because when we first immigrated to Canada, we did not speak any English. Because we didn't have jobs, our money ran out very quickly, which made us realize how badly we needed to find work. The winter of 1971 was very difficult - we had no money and neither of us had a job. Later, I found a job at the factory where I worked for the following 12 years. The following 12 years I took care of my grandchildren, and the last 12 years I
Green card: All migrants need certain documentation when migrating. Without this, such as a green card, immigration is prohibited or illegal.

Infectious diseases:

Immigration countries wanted to ensure that new immigrants who would settle in their land would not bring any infectious diseases. Therefore, they wanted all immigrants to go through medical examinations (Ilc Klun, 2017).

Toronto: The metropolitan area of Toronto is the city in Canada in which the largest number of members of the Slovenian are located. According to statistical data, around 10.000 people of Slovenian descent live there (Ilc Klun, 2017).

Guarantee letter: This was a letter which all new immigrants who wanted to settle in Canada or the USA needed. This needed to state that the immigrant would have financial support, a place to live and a job when they arrived. Usually guarantee letters were written by a relative or a friend who had already been living in the city for a few years (Ilc, 2006).

Stay in Canada for five years: At first, many Slovenians who emigrated in the 20th century did not want to stay in the target 
was employed in a store. As job opportunities increased, my husband became qualified to be a construction worker.

Shortly after we immigrated to Toronto, we met other Slovenians and connected with them through the Slovenian church. We still socialize with the Slovenian community through various church meetings, such as festivals, celebrations, banquets, and dinners. In some ways, I think it was easier for us to integrate into a new society because we were pretty young - 22 and 24 years old. When we immigrated to Toronto, we experienced some differences between Slovenians in Slovenia and those living in Canada. For instance, in Slovenia each family member kept to themselves. Men went to the bars, while woman and children were waiting for them at home. In Canada, families live together, they are very close with one another. During the week, men and women are working, and during the weekends they socialize with other family members, relatives, and friends. In my opinion, family connections in Canada are much stronger than in Slovenia. If I had to choose again, I would not change anything and I do not have any regrets. Canada is now my homeland, where I have my husband, children, grandchildren, friends, and relatives. I talk with my mother, who still lives in Slovenia, each day over the phone. We get to talk every week and discuss things like the news and current events within our countries. As a young girl I travelled to Canada, and as a woman I have created a great life here and one day, as an old woman, I will be buried here." (Ilc Klun, 2017b) country forever. They wanted to earn some money and then return to their homeland. For example, in the first decades of the 20 th century, around $25 \%$ of Slovenian emigrants returned to Slovenia (Valenčič, 1990).

Did not speak any English: When immigrating to Canada or the USA, the majority of Slovenian emigrants did not speak English. Therefore, they spoke to their family members only in Slovenian.

Other Slovenians - Slovenian community: Many Slovenian emigrants felt the need to be an active part of a Slovenian community in the city where they settled. One of the most important parts such a community was the Slovenian church.

Homeland: Due to various reasons, mainly economic and political, Slovenian emigrants left their homeland and then found, after settling permanently, a new homeland in a new country. Some Slovenian emigrants speak about their "old homeland" when they think of Slovenia, and their "new homeland" when they think of the country where they now reside (Ilc Klun, 2017). 
Table 3: The real life story of a person of from Slovenia who immigrated to Australia.

With a hope and desire to the other end of the world (Joe, Australia)

"It was in 1958 when I first came to

Australia. I was only 18 years old, and a month later I celebrated my 19th birthday. I emigrated from Slovenia on Christmas Day in 1957. I arrived in Australia on 26 January 1958 at 8 am. I travelled with the ship Sydney from Trieste to Sydney. I remember that it was a great day. Since then, 57 years have passed, and all the memories have remained. In Australia, they celebrate the Australia Day on January 26, so every year on that date, I also celebrate the day of my arrival to Australia.

I emigrated to Australia to find a better life. My brother and cousins had already lived in Sydney - they emigrated there a few years before me. I also had a sister here, but she had already died. When I came to Australia, I lived with my brother.

At that time, it was not hard to get a job in Australia. The city of Sydney began to expand and a large number of homes, roads and railways were built. In 1958 the Opera House was built, which became an important tourist destination along with the Sydney Harbour Bridge, which was built in 1932. I met good people in Australia. They helped me find work and a home. At times, I worked three jobs. Later I lived near the building where I worked for 20 years. I worked in the kitchen and I really liked the job.

When I immigrated to Australia I could not leave the country for five years until I got an Australian passport. After six years was
Analysing facts of the story building up knowledge

All the memories remained: Many Slovenian emigrants remember the exact dates of their emigration and immigration. Their memories of the migration process are clear and precise: they remember dates, hours, people, names of ships, etc. All of these are important parts of their individual memories, which in some way also connect them to their place of origin.

To find a better life: Finding a better life was the most common reason why Slovenians emigrated in the 20th century. Because of this, 300,000 people, a third of the Slovenian population at the time, emigrated between the end of the 19th century and 1914 (Drnovšek, 1999).

It was not hard to get a job: In the first half of the 20th century, the majority of Slovenian emigrants did not have problems finding a job. They were known for their hard work, which appealed to their employers. I visited Slovenia: One of the important connections that Slovenian emigrants keep with their place of origin are visits to their (old) homeland (Ilc, 2006). 
the first time that I visited Slovenia because my mother became sick. I also met my wife in Australia, who came from Prekmurje. In 1970, we got married in a Slovenian church. In 1974, we had our first daughter, then in 1980, a son. Both were born in Australia. The youngest daughter was born in Slovenia because my wife decided to return to

Slovenia along with my oldest daughter and son. My wife had never liked Australia, even though she spent more than 10 years there. In 1986, she came back to Australia with all our children, but not for a long time. They only stayed here for a year and a half. My wife did not feel good in this environment - she was always tired in Sydney and often felt sick. All of her family lived in Prekmurje which meant she was alone in Australia. Eventually she decided to leave Australia forever. That's how I stayed alone. All of our children grew up in Slovenia. I have never divorced my wife, although we have lived separately now for 26 years, each of us in our own end of the world. I only visited her once in 2000, when I retired. Now my youngest daughter lives with me in Australia. Due to my age and illness, I can no longer live by myself.

Australia is no longer the country it was before. It got warmer and many immigrants from all over the world have come to Australia. Before, I could leave my house open and not be afraid of someone stealing something from me. Now, there is a lot of crime within the city. The number of inhabitants has also tripled. Time runs very fast and everything has changed ..." (Ilc Klun, 2017b)
It all depends on how strong the emotions toward Slovenia are, but there are some emigrants who have visited their homeland over 20 times (Ilc, 2006). My wife: Many Slovenian emigrants marry other Slovenians - either those who emigrated from Slovenia or those who have Slovenian ancestors. The reasons for this are likely cultural, linguistic, and ethnic.

\section{To return to Slovenia:}

Remigration to Slovenia was also a migration process for some Slovenian emigrants. There were various reasons for remigration, one of the most common being family. 
Presented about are three real life stories that are good examples of how teachers could use life stories to teach migration-related topics. In each story, several migrationrelated issues are discussed, which we analysed in the second columns of Tables 1-3. In the case of real life stories, the topics of migration and Slovenian emigration are not presented in an ordinary way, like they are at school, where statistical data and the locations of emigration and immigration routes prevail. In the case of real life stories, the memories of individual migrants are told, and through these we gain a deeper perspective on the actual migration process. Real life stories can also give us cultural, social, and personal aspects of migration. In our opinion, teaching young people about migration through real life stories can help students better understand the related processes. Also, a story gives students an opportunity to put themselves in the position of the migrant and reflect on how they might react if they were in that situation.

The book Stories - often told but never written stories of people of Slovenian descent from USA, Canada, Australia and New Zealand was very well received among geography teachers and teachers-to-be, to whom the book was presented. In the interviews, conducted in the period 2017-2018, they concluded that the "real life story teaching approach" is a good way to teach about Slovenian emigration, so that students could better understand some related issues. The teachers also agreed that this approach is a good way to teach general topics related to migration, because in real life stories such issues are presented. The teachers also noted that stories can be used with different school subjects when teachers or students want to discuss presentday migration processes. One teacher also pointed out that the real life stories from the book can be useful when an immigrant child joins a class, as the memories and emotions attached to each story would help their classmates to better understand that every migrant goes through the same processes - that of emigration and that of immigration. This was the case with regard to Slovenian emigration and it is still the case for present-day global migrants. In our opinion, life stories should be incorporated in teaching as material that the teacher can use to teach, discuss and research migration-related topics with students.

\section{Conclusion}

Migration is becoming more and more common, and therefore increasingly linked to our everyday lives, appearing almost daily in the media. It is therefore important that issues related to migration become a part of the compulsory learning content in school systems. Research conducted in the Slovene school system between the years 2015-2018 showed that migration is not adequately discussed in class, that 
migration related topics are not part of the obligatory learning content, and that pupils do not find issues related migration and Slovenian emigration, as currently presented, interesting. In foreign educational systems (e.g. the USA, the UK and Australia), the narratives have recently been used to teach various different humangeography related topics (poverty, migration, and so on), which, according to the teachers, have been very well received in class. Therefore, we decided to develop a teaching tool which consists of the narratives and real life stories of Slovenian emigrants and their descendants. Through these stories, students can learn not just about the historical facts of Slovenian emigration, but can also gain a more comprehensive, in-depth overview of the related processes. The stories do not show a global overview of Slovenian emigration, but instead focus on individual memories and interpretations. This teaching tool has been used and tested at different educational levels in the Slovenian school system, and it was presented at different conferences and congresses for teachers (Freiburg, 2017, Brdo pri Kranju, 2018, Brežice, 2018, Ljubljana, 2018, Maribor, 2017, Washington DC, 2019), where it was very well received.

\section{References}

Cameron, E., New Geographies of Story and Storytelling, Progress in Human Geography 36/5, 2012, pp. 573-592.

Clark, M. C., Narrative learning: its contours and its possibilities, New directions for adult and continuing education 126, 2010, pp. 3-11.

Clark, M. C. et al., Narrative learning in adulthood, New directions for adult and continuing education 119, 2008, pp. 61-70.

Drnovšek, M., Pot slovenskih izseljencev na tuje, Ljubljana 1991.

Drnovšek, M., Izseljevanje Slovencev v razvite evropske države do leta 1940, Slovenska izseljenska književnost, vol. 1 (eds. Žitnik Serafin J., Glušič, H.), Ljubljana 1999, pp. 29-60.

Drnovšek, M. et al., Množično izseljevanje Slovencev v Združene države Amerike (priročnik za učitelje), Ljubljana 2002.

Drnovšek, M., Vzroki izseljevanja Slovencev v zadnjih dveh stoletjih, 2017, http:// www2.arnes.si/ krsrd1/conference/Speeches/Drnovsek_slo.htm [25. 8. 2018].

Goodson, I. F. et al., Narrative Pedagogy, Life History and Learning. Studies in Postmodern Theory of Education, New York 2011.

Ilc, M., Ameriški Slovenci ali Američani s slovenskimi koreninami v metropolitanskem območju Clevelanda [diplomsko delo], Univerza v Ljubljani, Ljubljana 2006. 
Ilc Klun, M., Teoretična in terminološka izhodišča izseljenstva ter poznavanje tematik izseljenstva med slovenskimi učenci in dijaki, Dela 41, 2014, pp. 165-181.

Ilc Klun, M., Slovensko izseljenstvo in diaspora v procesu geografskega izobraževanja [doktorska disertacija], Univerza v Ljubljani, Ljubljana 2017.

Ilc Klun, M., Thinking, teaching and learning about migration processes: The case of Slovenia. Unity in diversity: European perspective on borders and memories (ed. Mentz, O., McKay, T.), Zurich 2017a, pp. 118-132.

Ilc Klun, M., Zgodbe - velikokrat izrečene, a nikoli zapisane zgodbe ljudi slovenskih korenin iz ZDA, Kanade, Avstralije in Nove Zelandije, Ljubljana 2017b.

International Migration Report 2013, United Nations, Department of Economic and Social Affairs, Population Division, New York 2013.

International Migration Report 2015, United Nations. Department of Economic and Social Affairs, Population Division, New York 2016.

Kovač, B., Globalizacija, migracijski tokovi in ekonomski razvoj na obrobju slovenskih migracijskih dilem, in: Migracije - globalizacija - Evropska unija, Ljubljana 2003, pp. $43-82$.

Kragh Blume Dahl, K., Narrative learning through life: Kenyan teachers' life-stories and narrative learning, and what this means for their relation to the teaching profession, International Journal of Educational Development 40, Copenhagen 2015, pp. 145-155.

Malačič, J., Imigracije in trg dela v Sloveniji: od priseljevanja sodržavljanov do zaposlovanja tujcev, Naše gospodarstvo 54/1-2, 2008, pp. 45-53.

Malačič, J., Zunanje migracije Slovenije po drugi svetovni vojni, Zgodovinski časopis 45/2, 1991, pp. 299-313.

Meares, C., A fine balance: Women, work and skilled migration, Women's Studies International Forum 33/5, 2010, pp. 473-481.

Pajnik, M. et al., Biografski narativni intervju: aplikacija na študije migracij, Dve domovini 30, 2009, pp. 69-89.

Papademetriou, D. G., The Age of Mobility. How to get more out of migration in the $21^{\text {st }}$ century, 2007, Migration Policy Institute, March, 2007, https://www. migrationpolicy.org/sites/default/files/publications/age_mobility_032307.pdf [15. 7. 2018].

Population Facts, United Nations, Department of Economic and Social Affairs, Population Division, New York 2017, http://www.un.org/en/development/desa/ population/publications/pdf/popfacts/PopFacts_2017-5.pdf [15. 7. 2017]. 
Roseneil, S., Using biographical narrative and life story methods to research women's movements: FEMCIT, Women's Studies International Forum 35/3, 2012, pp. 129-131.

Salzmann, T. et al. (eds.), Demographic Aspects of Migration, Wiesbaden 2010.

SURS, Izseljevanje iz Slovenije v obdobju 1961-2017, 2018, http://pxweb.stat.si/pxweb/ Dialog/Saveshow.asp [1. 8. 2018].

Valenčič, V., Izseljevanje Slovencev v tujino do druge svetovne vojne, Dve domovini 1, 1990, pp. 43-82.

Wengraf, T., The Biographic-Narrative Interpretative Method (BINM), London 2004.

Zupančič, J., Identiteta je merljiva. Prispevek k metodologiji proučevanja etnične identitete, Razprave in gradivo 33, 1998, pp. 253-268. 


\section{Mojca Ilc Klun}

\section{Pomen individualnih spominov izseljencev pri interpretaciji slovenskega izseljenstva}

Ključne besede: slovensko izseljenstvo, diaspora, migracije, biografsko-narativni metodološki pristop, življenjske zgodbe, spomini

Slovensko izseljenstvo je velikokrat predstavljeno s splošnim orisom, v katerem prevladujejo faktografski podatki in statistična dejstva, medtem ko so iz teh opisov individualne izkušnje in spomini izseljencev izpuščeni. V raziskavi, ki smo jo z uporabo biografsko-narativnega metodološkega pristopa izvedli med slovenskimi izseljenci iz Združenih držav Amerike, Kanade in Avstralije, so nas zanimale življenjske zgodbe in spomini tistih, ki so se iz Slovenije izselili sami, in tistih, katerih predniki so se izselili iz Slovenije. S pomočjo življenjskih zgodb in spominov lahko slovensko izseljenstvo predstavimo tako, da bomo lahko bolje razumeli tudi globalne migracijske procese. $\mathrm{V}$ prispevku so v treh doživetih resničnih življenjskih zgodbah slovenskih izseljencev predstavljeni njihovi individualni spomini ter predstave o njihovem izvornem okolju, domovini in novem socialnem okolju priselitve. 
Mojca Ilc Klun

\section{The Importance of Individual Memories of Slovenian Emigrants when Interpreting Slovenian Emigration Processes}

Keywords: Slovenian emigration, diaspora, migration, biographical-narrative methodological approach, life stories, memories

Slovenian emigration is often presented with a general overview in which general data and statistical facts prevail, while the individual experiences and memories of Slovenian emigrants are omitted from these descriptions. In the study, which was conducted using a biographical-narrative methodological approach among members of the Slovenian diaspora from the United States of America, Canada and Australia, we were interested in the personal experiences and memories of those who emigrated from Slovenia themselves, or whose ancestors did. Through those life stories and memories, we can illustrate Slovenian emigration processes in such a way that people would better understand global migration processes. In the article we present three real life stories of members of the Slovenian diaspora, their individual memories and perceptions of their place of origin, homeland, the memories of emigration and immigration processes and memories of integration to the new social environments. 